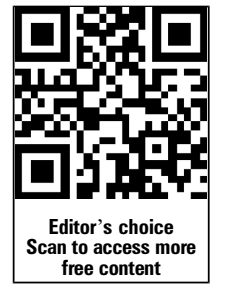

- Additional material is published online only. To view please visit the journal online (http://dx.doi.org/10.1136/ gutjnl-2013-306709).

For numbered affiliations see end of article.

Correspondence to Professor Geert D'Haens, Department of

Gastroenterology and Hepatology, Academic Medical Center, University of Amsterdam, Meibergdreef 9 , Amsterdam 1105 AZ, The Netherlands; g.dhaens@amc.uva.nl

Received 3 January 2014 Revised 17 May 2014 Accepted 28 May 2014 Published Online First 20 June 2014
CrossMark

To cite: Gecse $K B$ Bemelman W, Kamm MA, et al. Gut 2014;63: 1381-1392.

\title{
A global consensus on the classification, diagnosis and multidisciplinary treatment of perianal fistulising Crohn's disease
}

\author{
Krisztina B Gecse, ${ }^{1,2}$ Willem Bemelman, ${ }^{3}$ Michael A Kamm, ${ }_{1}^{4}$ Jaap Stoker, ${ }^{5}$ \\ Reena Khanna, ${ }^{6,7}$ Siew C Ng, Julián Panés, ${ }^{9}$ Gert van Assche, ${ }^{10}$ Zhanju Liu, ${ }^{11}$ \\ Ailsa Hart, ${ }^{12,13}$ Barrett G Levesque, ${ }^{14,15}$ Geert D'Haens, ${ }^{1,2}$ for the World \\ Gastroenterology Organization, International Organisation for Inflammatory Bowel \\ Diseases IOIBD, European Society of Coloproctology and Robarts Clinical Trials
}

\section{ABSTRACT \\ Objective To develop a consensus on the classification, diagnosis and multidisciplinary treatment of perianal fistulising Crohn's disease (pCD), based on best available evidence.}

Methods Based on a systematic literature review, statements were formed, discussed and approved in multiple rounds by the 20 working group participants. Consensus was defined as at least $80 \%$ agreement among voters. Evidence was assessed using the modified GRADE (Grading of Recommendations Assessment, Development, and Evaluation) criteria.

Results Highest diagnostic accuracy can only be established if a combination of modalities is used. Drainage of sepsis is always first line therapy before initiating immunosuppressive treatment. Mucosal healing is the goal in the presence of proctitis. Whereas antibiotics and thiopurines have a role as adjunctive treatments in PCD, anti-tumour necrosis factor (anti-TNF) is the current gold standard. The efficacy of infliximab is best documented although adalimumab and certolizumab pegol are moderately effective. Oral tacrolimus could be used in patients failing anti-TNF therapy. Definite surgical repair is only of consideration in the absence of luminal inflammation.

Conclusions Based on a multidisciplinary approach, items relevant for fistula management were identified and algorithms on diagnosis and treatment of $\mathrm{PCD}$ were developed.

\section{INTRODUCTION}

Penner and Crohn first described perianal fistulas as complications of Crohn's disease (CD) 75 years ago. ${ }^{1}$ Population based studies confirmed that perianal fistulas are the most common manifestation of fistulising CD, developing in 20\% of Crohn's patients and recurring in approximately $30 \%$ of the cases. $^{2} 3$ The cumulative incidence of perianal fistulising CD (pCD) is $12 \%$ after 1 year and this doubles 20 years after diagnosis. ${ }^{2}$ The risk of developing a fistula depends on disease location, being most frequent in colonic disease with rectal involvement. ${ }^{3}$ Perianal fistulas impose a significant burden on the patients. Unfortunately there are limitations in the available literature, making it challenging to develop an evidence based approach to $\mathrm{pCD}$. The objective of the working group was to develop a consensus on the classification, diagnosis and treatment of pCD, based on best available evidence and expert opinion in order to offer guidance to clinicians.

\section{METHODS}

\section{Working group}

The World Congress of Gastroenterology 2013 called for the development of state-of-the-art, evidence based views for designated areas of gastroenterology. An expert consensus group on pCD was formed and a literature review process (summarised in online supplementary figure S1) followed, covering all relevant papers and abstracts until March 2014. The search initially identified 4680 references. A selection process by the research committee members and additional references identified by manual search led to 247 retained articles.

\section{Consensus process}

Four areas of interest were identified: (1) classification and scoring, (2) diagnosis, (3) medical treatment, and (4) surgical management. For each of these areas the research committee drafted statements based on the systematic literature review and developed potential algorithms. These were discussed and revised by the group during their meetings. As a final step all participants voted on each statement, using definitions of agreement previously reported by Bitton et $\mathrm{al}^{4}{ }^{4}$ Consensus was a priori defined as at least $80 \%$ agreement. The modified GRADE (Grading of Recommendations Assessment, Development, and Evaluation) criteria were used to establish the strength of recommendations and the quality of evidence (see online supplementary table S1). ${ }^{5}$

\section{CONSENSUS STATEMENTS}

Section 1: Classification and scoring

Statement 1-General considerations for classification and scoring

1.1 A clinically useful classification of perianal fistulas in CD should enable the treating physician to determine optimal management strategy.

Vote: $A+=80 \%, A=15 \%, D=5 \%$; grade of recommendation: $1 \mathrm{C}$

1.2 Scoring of perianal fistula activity in CD should enable the treating physician to evaluate disease severity and response to therapy. 
Vote: $A+=70 \%, A=20 \%, A-=5 \%, D-=5 \%$; grade of recommendation: $1 \mathrm{C}$

Discussion Several classification and scoring systems have been developed in an attempt to quantify disease extent and severity of pCD. ${ }^{6-16}$ We propose that a distinction is made between a detailed anatomic description of perianal fistulas (ie, classification) and the assessment of fistula activity (scoring), a dynamic measure that is sensitive to change under treatment. However, both components are necessary to design an optimal therapeutic strategy and are relevant for prognosis (table 1).

\section{Statement 2-Fistula activity}

Evaluation of fistula activity is recommended both by clinical and radiological (MRI) features.

Vote: $A+=70 \%, A=20 \%, A-=5 \%, D+=5 \%$; grade of recommendation: $2 \mathrm{C}$

Discussion The Perianal Disease Activity Index (PDAI) is based on the assessment of quality of life (pain/restriction of activities and restriction of sexual activities) and perianal disease severity (fistula discharge, type of perianal disease, and degree of induration) rated on a five-point Likert scale. ${ }^{13}$ It was tested for reliability and responsiveness and was validated against physicians' and patients' global assessments. ${ }^{13}$ A cut-off PDAI score $>4$ resulted in $87 \%$ accuracy when using clinical assessment (active fistula drainage and/or signs of local inflammation) as reference. ${ }^{17}$ 'Fistula drainage assessment' was first used to quantify fistula healing in a randomised controlled trial (RCT) with infliximab. ${ }^{14} \mathrm{~A}$ fistula was considered 'closed' when it no longer drained despite gentle finger compression. A response was defined as a reduction of $50 \%$ or more in the number of draining fistulas on at least two consecutives visits. Fistula remission was defined as the absence of any draining fistulas on two consecutive visits. Although this clinical assessment has been used in further RCTs, it has several drawbacks. ${ }^{18-20}$ 'Gentle finger compression' is largely investigator dependent and is an approach that has never been formally validated. Persistent tracts without fluid drainage are scored as 'remission'. Moreover, the external appearance of the fistula is used as a surrogate for the whole internal fistula tract. MRI studies have shown that internal fistula healing lags behind clinical remission by a median of 12 months. $^{21}$ The site of a former/residual fistula tract could be the path of least resistance for a new or recurrent fistula tract to occur. ${ }^{22}$ In an attempt to combine anatomical fistula description and features reflecting active inflammation, van Assche et al ${ }^{16}$ developed an MRI based scoring system. Anatomical components include the number and course of the fistula tracts, while the activity of inflammation was evaluated by hyperintensity of fistula tracts on T2 weighted MRI images, the presence of abscess and proctitis. ${ }^{16}$ The score was validated against the PDAI but had a weak correlation $(\mathrm{r}=0.371, \mathrm{p}=0.036) .^{22}$ One year of infliximab therapy was associated with significant improvement of the Van Assche score, particularly for the item T2 hyperintensity. ${ }^{23}$ Disappearance of contrast enhancement was the only MR feature associated with clinical remission. ${ }^{23}$ In a more recent study, this score was found to be insensitive to change in patients with reduced fistula calibre during long term follow-up. ${ }^{21}$ Recently, perianal fistula length assessed by MRI was found to be a predictor of response to treatment. ${ }^{24}$ In conclusion, improved instruments to score perianal CD fistula activity are needed.

\section{Statement 3-Fistula anatomy}

3.1 The course of the fistula tract in relation to the anal sphincter and the levator plate (superficial, intersphincteric, transsphincteric, suprasphincteric, extrasphincteric, and supralevator or infralevator) is an important component for classification.

Vote: $A+=90 \%, A=5 \%, D-=5 \%$; grade of recommendation: $2 B$

3.2 High and low transsphincteric fistulas should be distinguished in the classification. Fistulas are defined as low when the tract runs through the lower one third of the external anal sphincter.

Vote: $A+=70 \%, A=20 \%, A-=10 \%$; grade of recommendation: $2 \mathrm{C}$

Discussion Parks et $a l^{6}$ studied the anatomy of perianal fistulas and the associated risk of post-surgical incontinence in 400 consecutive patients, as illustrated in figure 1 . Section 4 describes the impact of fistula anatomy on surgical treatment.

\section{Statement 4-Proctitis}

The presence of proctitis, defined as any ulceration and/or stricture in the rectum, or inflammation and/or stricture of the anal canal, is an important component for fistula assessment. Vote: $A+=90 \%, A=10 \%$; grade of recommendation: $1 \mathrm{C}$

Discussion The presence of proctitis is highly relevant for fistula management and prognosis as discussed in detail in sections 3 and 4.

\section{Statement 5-Abscess}

A perianal abscess clinically defined as fluctuation and radiologically defined as a confined fluid collection (a hyperintense lesion on T2 weighted MRI images and/or a hypo- or anechoic area with endoanal ultrasound (EUS)) with a rim of inflammatory tissue (rim enhancement on post-contrast T1 weighted MRI images and/or often poorly demarcated lesions on EUS) is an important component for classification.

Vote: $A+=55 \%, A=35 \%, A-=10 \%$; grade of recommendation: $2 \mathrm{C}$

Discussion Perianal CD fistulas are frequently accompanied by abscess formation. Timely detection and management of abscesses minimises the risk of further septic complications. Items found to be clinically relevant for fistula management are depicted in figure 1.

Table 1 Descriptive and dynamic measures to evaluate perianal fistulas

\begin{tabular}{|c|c|c|}
\hline \multirow[b]{2}{*}{ Descriptive } & \multicolumn{2}{|l|}{ Dynamic } \\
\hline & Clinical & Clinical and MRI \\
\hline Milligan and Morgan & Present $^{11}$ & Van Assche Score ${ }^{16}$ \\
\hline Parks/modified Parks ${ }^{6}$ & Anal Disease Activity Index ${ }^{12}$ & \\
\hline Buchmann/Alexander-Williams ${ }^{7}$ & Perianal Disease Activity Index (PDAI) ${ }^{13}$ & \\
\hline Cardiff $^{8}$ & Fistula Drainage Assessment ${ }^{14}$ & \\
\hline St James University Hospital ${ }^{9}$ & Pikarsky's Perianal Crohn's Disease Activity Index ${ }^{15}$ & \\
\hline AGA Technical Review ${ }^{10}$ & & \\
\hline
\end{tabular}




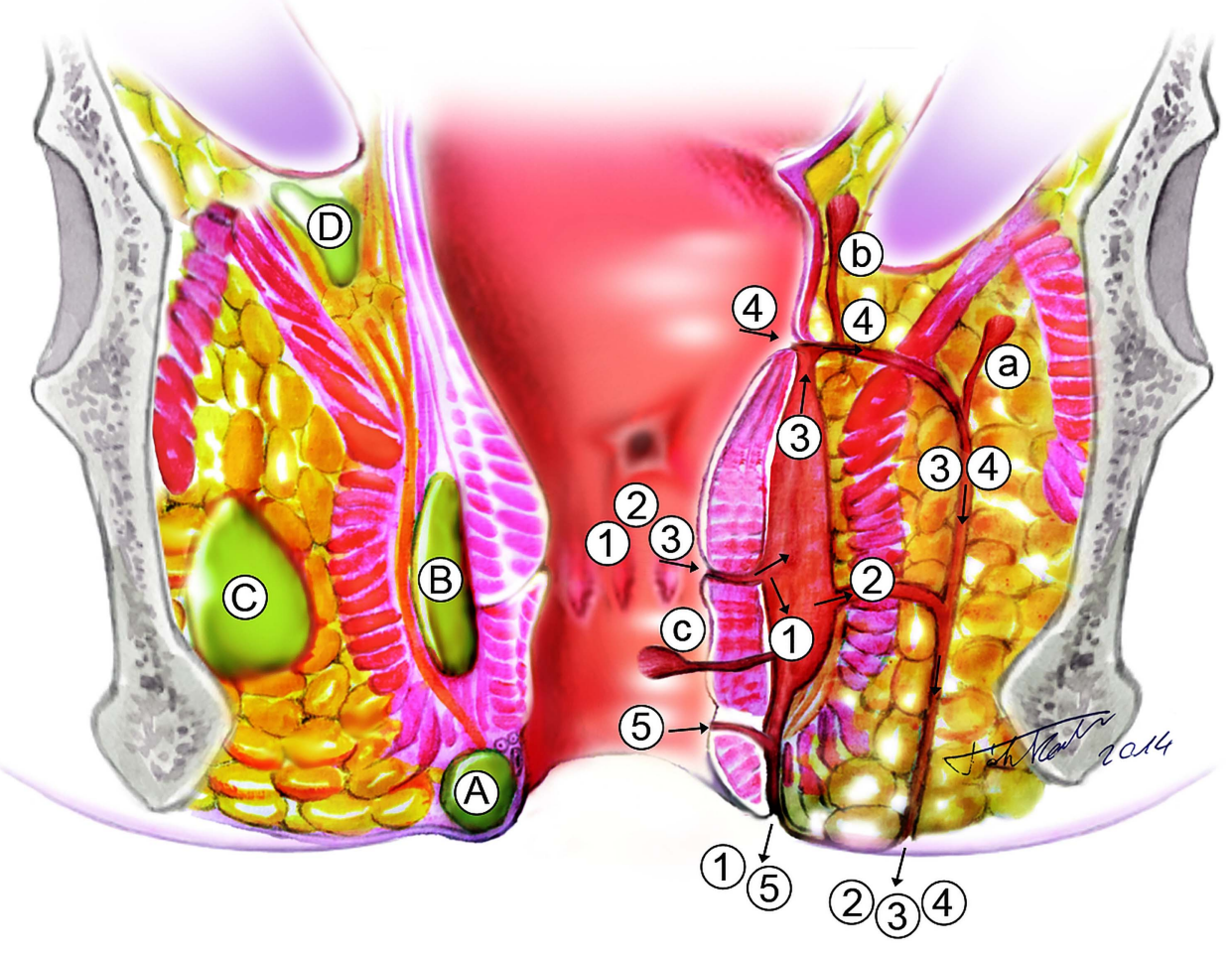

Figure 1 Disease characteristics relevant for fistula management. A fistula is a tract of pus and/or granulation tissue between two epithelial surfaces lined with a fibrous wall. ${ }^{10}$ Primary tracts are connections between the internal and external openings (1-5), while secondary tracts are blind extensions $(a-c)$. A tract is defined 'low' when it runs through the lower one third of the external anal sphincter. ${ }^{6}$ The course of the fistula tracts is described by the Parks classification. The external sphincter complex, defined by the external sphincter and the puborectal muscle, serves as reference: (1) intersphincteric: the tract penetrates the internal sphincter and runs through the intersphincteric space to the perianal skin; (2) transsphincteric: the tract penetrates both the internal and the external sphincter or the puborectal muscle; (3) suprasphincteric: tract runs first upwards in the intersphincteric space, then downwards crossing the levator ani muscle and then reaching the perianal skin; (4) extrasphincteric: tract originates from the rectal wall and runs down through the levator ani muscle, without penetrating the external sphincter or the puborectal muscle. ${ }^{6}$ Later a fifth category was added for superficial tracts (5) that did not involve the sphincter complex. Secondary tracts and their relationship to the levator plate (a) infralevator or (b) supralevator and (c) horizontal extension, also known as 'horseshoes', are distinguished. Furthermore proctitis and the presence of abscesses with regard to their localisation (A, perianal; B, intersphincteric; $C$, ischiorectal; $D$, suprasphincteric) are also noted.

\section{Section 2: Diagnosis and follow-up}

Statement 6-Endoscopy

Endoscopic assessment of the rectum is essential to determine the most appropriate management strategy.

Vote: $A+=85 \%, A=10 \%, A-=5 \%$; grade of recommendation: $1 \mathrm{C}$

Discussion Endoscopy allows assessment of the extent and severity of luminal inflammation, and the presence of internal openings and other complications such as strictures and cancer. ${ }^{25}$ Proctitis is a predictive factor of persistent non-healed fistula tracts and higher proctectomy rate. ${ }^{26}$

\section{Statement 7-Examination under anaesthesia}

Examination under anaesthesia (EUA) has an important role in the diagnosis and classification of pCD. It also allows immediate therapeutic intervention such as abscess drainage and/or seton placement. If a perianal abscess is suspected, EUA with drainage is the procedure of choice and should not be delayed if MRI is not immediately available. However, if additional collections are suspected, imaging is necessary.

Vote: $A+=50 \%, A=35 \%, A-=10 \%, D-=5 \%$; grade of recommendation: $1 \mathrm{C}$

Discussion Experienced colorectal surgeons are up to $90 \%$ accurate $(95 \%$ CI $78 \%$ to $98 \%)$ in detecting and classifying perianal fistulas, sinuses, and abscesses. ${ }^{27}$ As shown in a study with infliximab, higher success rates and lower recurrence rates were attained in patients who underwent EUA with abscess drainage and seton placement before starting anti-tumour necrosis factor (anti-TNF) treatment. ${ }^{28}$

\section{Statement 8-MRI}

8.1 Pelvic MRI is a highly accurate non-invasive modality for the diagnosis and classification of perianal fistulas; therefore it is considered the gold standard imaging technique for perianal CD. MRI provides additional detailed information on luminal disease location, disease severity, and fluid collections.

Vote: $A+=90 \%, A=10 \%$; grade of recommendation: $1 B$

Discussion MRI accurately visualises the anal sphincter and the pelvic floor muscles, as well as the fistula tracts and abscesses, with an accuracy ranging from $76-100 \%$ (figure 2 ). ${ }^{29-32}$ In addition, MRI may identify clinically 'silent' abscesses and luminal inflammation (figure 3). ${ }^{33} \mathrm{~T} 2$ weighted sequence with fat suppression is the optimal technique for MR fistula imaging. A gadolinium enhanced T1 weighted sequence is useful for the differentiation between fluid/pus and granulation tissue (table 2). Phased-array external coils have larger field of view with good coverage for supralevator fistulae. ${ }^{30}$ Endoanal coils provide an 

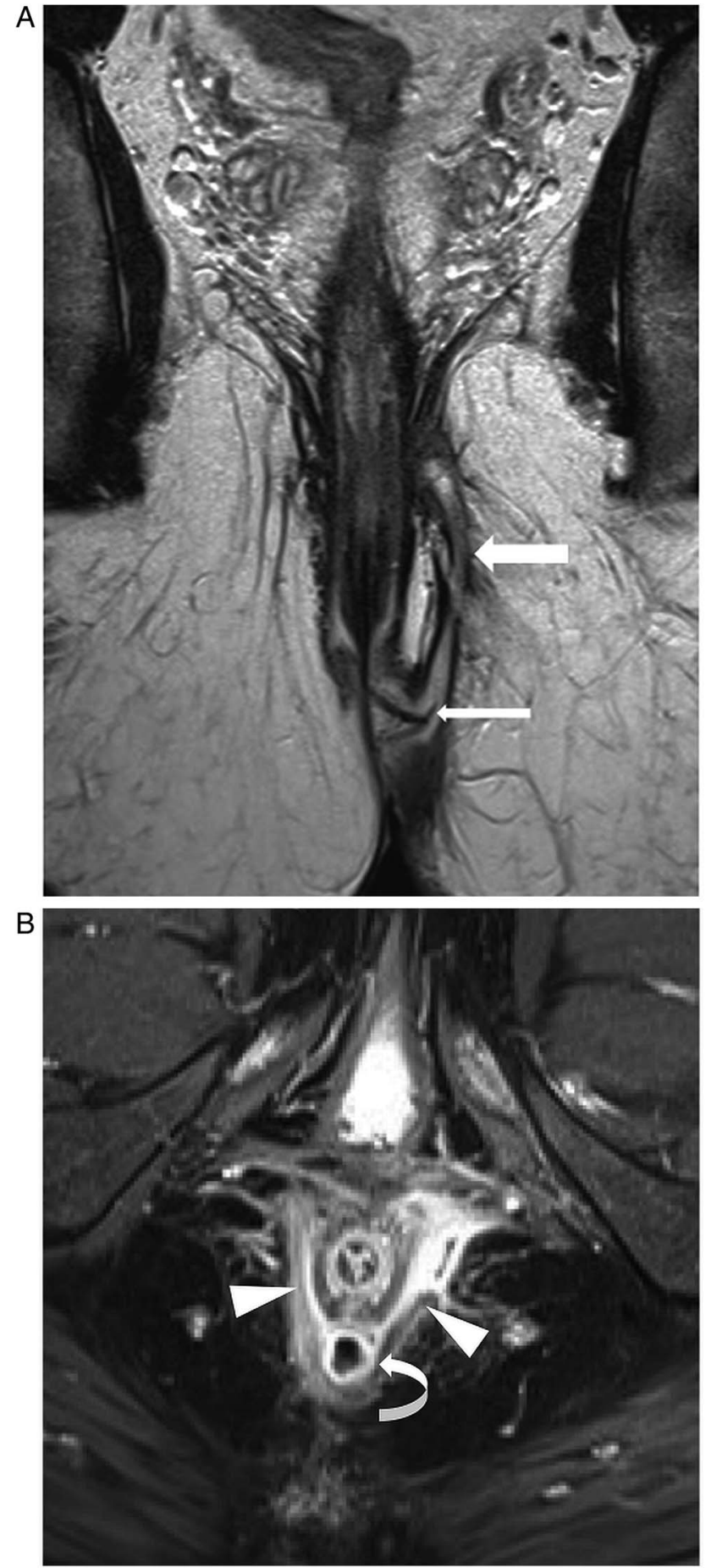

Figure 2 Representative MR image of a male patient with perianal fistulising Crohn's disease. (A) Coronal oblique T2 weighted turbo spin-echo sequence and (B) axial oblique fat saturated T1 weighted turbo spin-echo sequence demonstrate a transsphincteric fistula (arrow) with a seton in place (thin arrow), an intersphincteric abscess (curved arrow) with bilateral granulation tissue filled extensions (arrowheads) in the puborectal muscle.

advantage in identifying internal openings; however, they are less widely available and have a restricted field of view. ${ }^{34}$

\section{Statement 9-Endoanal ultrasound}

EUS (with or without hydrogen peroxide) is a useful alternative to MRI in diagnosing perianal CD fistulas; however, accuracy can be limited by its restricted view.

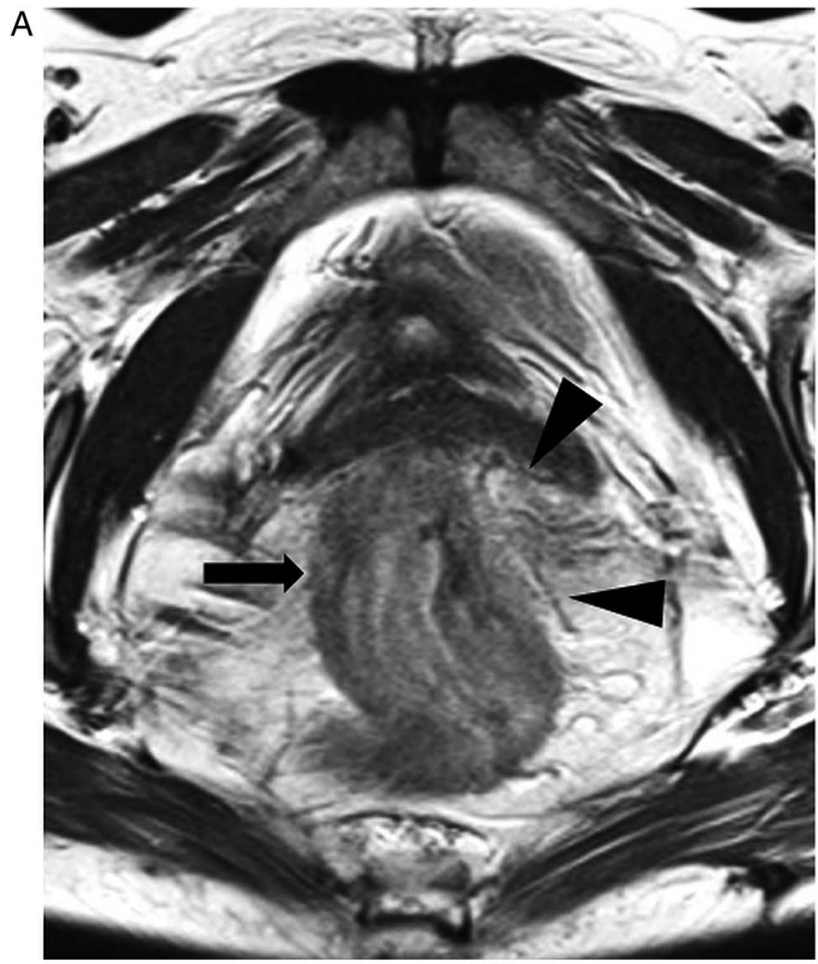

B

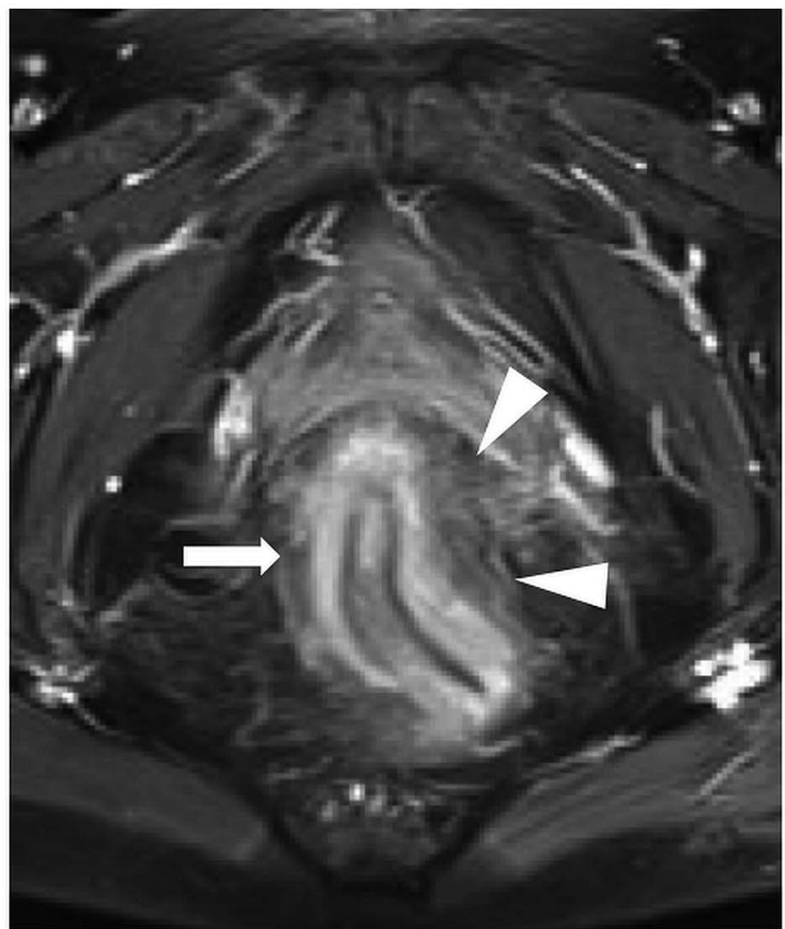

Figure 3 Representative MR image of a female patient with perianal fistulising Crohn's disease and proctitis. (A) Axial oblique T2 weighted turbo spin-echo sequence and (B) axial oblique fat saturated T1 weighted turbo spin-echo sequence show a thickened rectal wall (arrow), with increased enhancement and surrounding infiltrate (arrowheads).

Vote: $A+=50 \%, A=45 \%, D-=5 \%$; grade of recommendation: $2 B$ Discussion EUS (with a frequency between $5-16 \mathrm{MHz}$ ) allows a detailed visualisation of the anal sphincter complex with accuracy between $86-95 \%$ for correct classification and 62-94\% for identification of internal openings. ${ }^{35-37}$ However, EUS cannot accurately identify ischioanal fossa or supralevator abscesses, as the penetration is limited. ${ }^{27}$ The use of endoluminal probes can 
Table 2 Interpretation of MRI

\begin{tabular}{lll}
\hline & T2 & Post-contrast T1 \\
\hline $\begin{array}{lll}\text { Fistula tract } \\
\text { Fibrosis }\end{array}$ & Hypointense & No enhancement \\
Pus/fluid & Hyperintense & No or rim only enhancement \\
Granulation tissue & Hyperintense & Enhancement \\
Abscess & Hyperintense & Rim enhancement \\
\hline
\end{tabular}

be restricted by luminal stenosis. In selected cases, local infusion of hydrogen peroxide or colour Doppler EUS with saline injection improves visualisation. ${ }^{38-40}$ When prospectively comparing hydrogen peroxide enhanced three dimensional EUS and endoluminal MRI with surgical assessment as reference, $81 \%$ and $90 \%$ agreement was found, respectively. ${ }^{41}$ Furthermore, the Crohn's Ultrasound Fistula Sign (CUFS) can differentiate between Crohn's related and cryptogenic fistulae-in-ano with a positive and negative predictive value of $87 \%$ and $93 \%$, respectively. ${ }^{42}$ As a complementary method, the accuracy of transperineal ultrasound to detect and classify fistulas was found to be comparable to EUS. However, its accuracy to diagnose deep abscesses is low (47.1\%) due to restricted field of view. ${ }^{43}$ Transperineal ultrasound may offer an advantage in detecting anovulvar fistulae $(88.9 \%$ vs $44.4 \%$ when compared with MRI). ${ }^{43}$ Both EUS and MRI are superior to clinical examination when assessing and monitoring perianal fistulas. ${ }^{27} 44-46$ In a meta-analysis of four studies comparing EUS and MRI, performance characteristics for MRI $(0.87,95 \%$ CI 0.63 to 0.96$)$ and EUS $(0.87,95 \%$ CI 0.70 to 0.95$)$ demonstrated comparable sensitivities in detecting perianal fistulas. The specificity for MRI $(0.69,95 \%$ CI 0.51 to 0.82$)$ was higher than that for EUS $(0.43,95 \%$ CI 0.21 to 0.69$) .{ }^{47}$ A comparison of EUS and MRI diagnostic features is summarised in table 3 . The choice mainly depends on local availability, expertise and the complexity of the $\mathrm{pCD}$.

\section{Statement 10-Fistulography and CT}

The diagnostic accuracy of fistulography and CT is poor in the diagnosis and classification of Crohn's perianal fistulas. Fistulography can, however, provide additional information in some exceptionally complex fistulas.

Vote: $A+=50 \%, A=35 \%, A-=5 \%, D=5 \%, D-=5 \%$; grade of recommendation: $1 C$

Table 3 EUS and MRI in the diagnosis of Crohn's perianal fistulas

\begin{tabular}{|c|c|c|}
\hline & EUS & MRI \\
\hline Simple fistulas & +++ & +++ \\
\hline Complex fistulas & ++ & +++ \\
\hline High tracts & ++ & +++ \\
\hline Abscess & ++ & +++ \\
\hline Internal openings & +++ & $++^{*}$ \\
\hline Availability & $-1+++$ & $+/++$ \\
\hline Costs & +++ & $+/++$ \\
\hline Overall accuracy & $62.5-95 \%$ & $76-100 \%$ \\
\hline
\end{tabular}

Discussion Fistulography and CT are outdated modalities in the diagnostic evaluation of pCD because of exposure to radiation and poor visualisation of the anatomic relationship of the fistulas to the pelvic floor muscles. ${ }^{48}$ Only in highly selected cases may fistulograms offer additional information and influence surgical management. ${ }^{49}$

Statement 11-Combination of diagnostic modalities

To ensure diagnostic accuracy and to determine an optimal management strategy, a combination of diagnostic modalities is recommended, namely endoscopy and MRI/EUS (depending on availability and expertise) and EUA.

Vote: $A+=60 \%, A=20 \%, D=10 \%, D-=10 \%$; grade of recommendation: $2 \mathrm{C}$

Discussion In a prospective study of 32 patients with perianal CD the accuracy of each diagnostic modality was excellent (EUS 91\%, EUA 91\%, MRI 87\%) and the combination of EUA with MRI or EUS increased accuracy to $100 \% .^{27} \mathrm{~A}$ diagnostic algorithm for Crohn's perianal fistulas is proposed in figure 4.

\section{Section 3: Medical treatment}

Statement 12-Treatment goals

The short term goals in the treatment of pCD are abscess drainage and reduction of symptoms. The long term goals are resolving fistula discharge, improvement in quality of life, fistula healing, preserving continence, and avoiding proctectomy with stoma.

Vote: $A+=90 \%, A=10 \%$; grade of recommendation: $1 \mathrm{C}$

\section{Statement 13-Corticosteroids and aminosalicylates}

There is no demonstrated role for aminosalicylates or corticosteroids in perianal CD.

Vote: $A+=90 \%, A=10 \%$; grade of recommendation: $1 \mathrm{C}$

Discussion Aminosalicylates have no clinical effect on perianal CD. ${ }^{50}$ Studies evaluating the effect of corticosteroid treatment

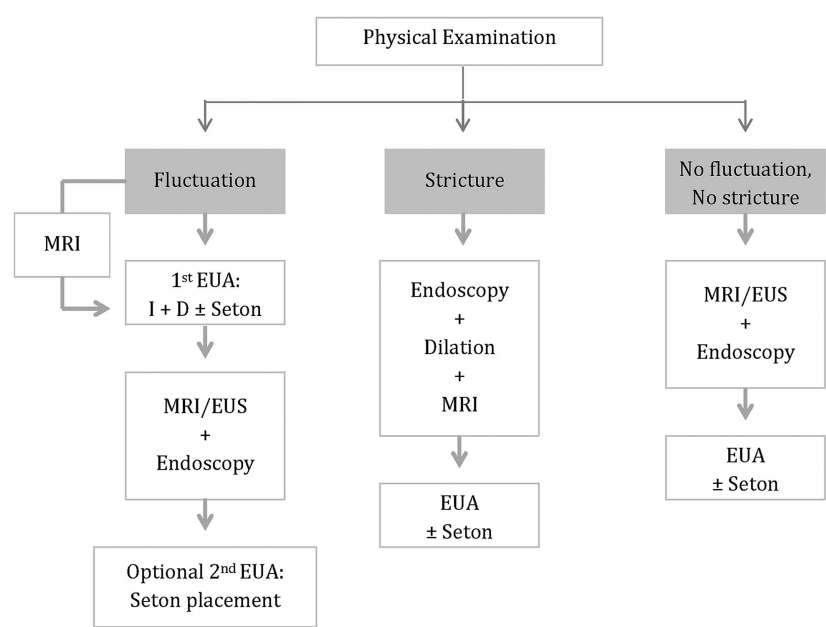

Figure 4 Diagnostic algorithm for perianal fistulising Crohn's disease. In perianal abscess is suspected, MRI is an optional diagnostic method, if readily available, before surgical incision and drainage. Alternatively diagnostic endoscopy can also be performed during examination under anaesthesia (EUA), to minimise patient discomfort. A second EUA might be necessary if seton placement is needed or was not successful upon the first EUA. When stricture is present, Bougie or gentle finger dilation is preferable to preserve sphincter function. EUS, endoanal ultrasound. 
in fistulising CD showed worsening of discharge and increased need for surgery. ${ }^{51}$

\section{Statement 14}

Antibiotics, namely metronidazole and ciprofloxacin, improve fistula symptoms and may contribute to healing.

Grade of recommendation: $1 \mathrm{C}$

Therefore, antibiotics are only recommended as adjunctive treatments for fistulas.

Vote: $A+=74 \%, A=16 \%, A-=10 \%$; grade of recommendation: $2 \mathrm{C}$

\section{Discussion}

Early small and uncontrolled series reported fistula improvement after 6-8 weeks of antibiotic therapy (metronidazole 750$1500 \mathrm{mg} /$ day, ciprofloxacin $500-1000 \mathrm{mg} /$ day) with frequent relapse upon discontinuation and commonly occurring side effects. ${ }^{52-54}$ Only one RCT comparing ciprofloxacin, metronidazole and placebo assessed the efficacy of systematic antibiotics for $\mathrm{pCD} .^{55}$ This short $(10$ weeks) and underpowered study $(n=25)$ showed no difference between antibiotics and placebo for fistula closure. ${ }^{55}$ Neither topical nor systemic metronidazole led to improvement of PDAI in prospective though small trials. $^{5657}$

Two double blind RCTs assessed the efficacy of ciprofloxacin combined with anti-TNF therapy. ${ }^{58} 59$ The first study combined ciprofloxacin with infliximab $(\mathrm{n}=24)$ and reported fistula response at week 18 in $73 \%$ of patients, versus $39 \%$ with infliximab alone $(p=0.12) .{ }^{58}$ In another RCT the effect of combination therapy with ciprofloxacin and adalimumab was superior to adalimumab monotherapy (in the reduction of at least $50 \%$ of the number of draining fistula in $70.6 \%$ vs $47.2 \%$ $(\mathrm{p}=0.047))$ at week $12 .{ }^{59}$ However, after discontinuation of ciprofloxacin the difference between the two groups diminished. Overall these results support the efficacy of antibiotics in reducing fistula drainage but not fistula healing.

\section{Statement 15}

Thiopurines may have a moderate effect in the treatment of pCD. Evidence for the efficacy of methotrexate and ciclosporin is limited. Tacrolimus is effective for treating active fistulas; when used, therapeutic drug monitoring is required to minimise toxicity.

Vote: $A+=32 \%, A=32 \%, A-=26 \%, D+=10 \%$; grade of recommendation: $2 \mathrm{C}$

\section{Discussion}

Thiopurines There is no prospective controlled trial involving azathioprine or 6-mercaptopurine with fistula outcome assessed as the primary end point. Available results are derived from a subgroup analysis of a randomised double blind study, where $31 \%$ of patients treated with 6 -mercaptopurine experienced complete fistula closure compared to $6 \%$ of the placebo patients. ${ }^{11} \mathrm{~A}$ recent meta-analysis excluding the above study did not show any efficacy of azathioprine for improving or closing fistulae (OR 4.68, 95\% CI 0.6 to $36.69 ; \mathrm{p}=0.14, \mathrm{n}=18$ ). ${ }^{60}$ In contrast, an earlier meta-analysis assessing the efficacy of thiopurines in 70 patients showed that $54 \%$ of patients treated with thiopurines had fistula healing versus $21 \%$ of patients treated with placebo (OR 4.44, 95\% CI 1.5 to 13.2). ${ }^{61}$ The effect of antibiotic and azathioprine combination therapy was evaluated in a prospective open label study and showed the superiority of the combination therapy $(p=0.03) .^{62}$
Methotrexate There are no clinically relevant trial data on the effect of methotrexate on draining fistulas.

Tacrolimus A single, short term, placebo controlled trial randomised 46 patients with actively draining Crohn's fistulas to treatment with oral tacrolimus or placebo. ${ }^{18}$ The primary end point-defined as the closure of at least $50 \%$ of fistulas maintained for at least 4 weeks-was reached in $43 \%$ on active treatment versus $8 \%$ on placebo $(\mathrm{p}=0.004)$. However, complete closure of all fistulas was not more common in the tacrolimus group. ${ }^{18}$ There was more nephrotoxicity with tacrolimus, which was managed by dose reduction. ${ }^{18}$ Topical tacrolimus showed no significant benefit. ${ }^{63}$

Ciclosporin Several observational studies reported on the efficacy of ciclosporin for fistulising CD. Clinical improvement was rapid, but relapse rates were high after drug discontinuation. ${ }^{64-66}$ Related adverse events limited further use of ciclosporin.

\section{Statement 16}

Infliximab (grade of recommendation: $1 A$ ) and adalimumab (1B) are moderately effective for the induction and maintenance of fistula closure. Evidence for efficacy of certolizumab pegol is weaker (1C). Anti-TNF and thiopurine combination therapy may lead to higher fistula healing response and closure rate compared to monotherapy $(2 \mathrm{C})$.

Vote: $A+=26 \%, A=42 \%, A-=16 \%, D=11 \%, D+=5 \%$.

\section{Discussion}

Infliximab Two RCTs have assessed the efficacy of infliximab in fistulising CD. In the first placebo controlled trial an induction regimen induced closure of at least $50 \%$ of fistulas for at least 4 weeks in $56-68 \%$ of patients compared with $26 \%$ treated with placebo $(\mathrm{p}=0.002$ and $\mathrm{p}=0.02$, respectively). Closure of all fistulas was achieved in $38-55 \%$ on infliximab. ${ }^{67}$ The ACCENT II trial further evaluated infliximab maintenance therapy for this indication. Week 14 responders to the induction regimen were randomised to further treatment with placebo or infliximab $5 \mathrm{mg} / \mathrm{kg}$ every 8 weeks. ${ }^{68}$ Time to loss of response was significantly longer on infliximab ( $>40$ weeks) than on placebo (14 weeks, $\mathrm{p}=0.001)$. Moreover, $39 \%$ of patients who received infliximab maintenance therapy had complete closure of all draining fistulas at week $54 .^{68}$

Adalimumab There has not been a dedicated controlled trial for fistulising $C D$ with adalimumab. In two placebo controlled trials, CLASSIC-1 and GAIN, the rates of fistula improvement and remission did not differ significantly in adalimumab treated patients at week 4 compared to placebo. ${ }^{69}{ }^{70}$ In the CHARM trial-a 56-week phase III trial to assess the efficacy of maintenance treatment with adalimumab among responders to induction treatment-a subgroup analysis in patients with draining fistula(s) at baseline showed complete fistula healing in 33\% of adalimumab treated patients versus in $13 \%$ of placebo treated patients $(p<0.05) .^{20}$ An open label extension of this trial showed sustained healing in $90 \%$ of patients on adalimumab treatment at 2 years follow-up. ${ }^{71}$ In further open label studies, adalimumab was effective in $23-29 \%$ of patients with fistulising $\mathrm{CD}$ who had lost response or become intolerant to infliximab. ${ }^{72-74}$

Certolizumab Subgroup analysis of PRECiSE 1 and 2-two large trials assessing the efficacy of certolizumab pegol for moderate to severe $\mathrm{CD}$-looked at fistula response. At week 26, $36 \%$ of patients on certolizumab pegol had complete fistula closure compared with $17 \%$ on placebo $(p=0.038){ }^{75}$ In contrast, no statistical difference was found in the rate of fistula response, defined as $>50 \%$ closure at two consecutive visits. ${ }^{75}$ 
A meta-analysis also evaluated the efficacy of anti-TNFs in pCD, and infliximab was found to have the most available evidence. ${ }^{76}$

Immunosuppression + anti-TNFs Data remain conflicting concerning the efficacy of concomitant immunosuppression with anti-TNF agents in pCD. Subgroup analysis of the ACCENT II trial found that concomitant immunosuppressants did not improve response rates to infliximab at 1 year. ${ }^{68}$ In the SONIC trial $12 \%$ of patients had perianal fistulas, but no separate analysis was performed in this group. Nevertheless, the gain with combination therapy is of particular interest in patients with proctitis. ${ }^{77}$ In support, recent studies suggest a clear association between combination therapy and fistula closure. ${ }^{78}$

Surgery and anti-TNFs In a large retrospective cohort, 218 patients underwent surgery alone or surgery plus biological therapy. Surgery included seton drainage, fistulotomy, rectal advancement flap, fistulotomy plus seton or other procedures. Clinical response was $35.9 \%$ in the surgery treated group and $71.3 \%$ in the combined treatment group $(p=0.001)$, suggesting that combined treatment modalities offer a better outcome. ${ }^{79}$

Experimental medical treatments are discussed in the online supplementary material.

\section{Section 4: Surgical management}

Statement 17-Abscess drainage

Surgical drainage of perianal abscesses is generally recommended before initiating medical therapy.

Vote: $A+=100 \%$; grade of recommendation: $1 \mathrm{C}$

Discussion In symptomatic perianal CD fistulas are frequently preceded or accompanied by perianal abscesses. ${ }^{80}$ Surgical drainage as opposed to spontaneous drainage minimises the risk of further septic complications aggravated by concomitant immunosuppressive treatment. ${ }^{81}$

\section{Statement 18-Setons}

Non-cutting seton placement is useful in order to prevent (recurrent) abscess formation.

Vote: $A+=85 \%, A=15 \%$; grade of recommendation: $1 C$

Discussion As all fistulas are potential sources of pelvic sepsis, ensuring adequate drainage is fundamental. Seton drains maintain patency of the fistula tracts and hence limit recurrent abscess formation. ${ }^{82}$ Loose setons preserve the integrity of the external anal sphincter and are to be preferred. ${ }^{83}$ In contrast, cutting setons carry a high risk of anal incontinence (54\%) due to scarring of the anal canal. ${ }^{84} \mathrm{~A}$ disadvantage of setons is that the fistula tract cannot 'close' with the seton in place. The optimal timing for seton removal is not well established. In the ACCENT 2 study, all setons were removed by week 2 and the overall new abscess rate was $15 \%$. Several other studies report maintaining seton(s) in situ for longer, thus seton removal at week 2 may be too early. ${ }^{19} 85$ In a small prospective trial, where setons were maintained for the duration of infliximab induction, the overall new abscess rate was $0 \% .{ }^{81}$ These results show that loose seton drainage is an efficient and safe method in the treatment of Crohn's perianal fistulas. It is recommended to keep the seton in place until at least the induction of the anti-TNF treatment period has been completed. Fistula closure can be achieved after seton removal.

\section{Statement 19-Proctitis}

The surgical treatment of pCD in patients with proctitis is limited to abscess drainage and non-cutting seton placement.
Further surgical attempt for fistula closure is recommended only after endoscopic remission of the proctitis has been achieved. Vote: $A+=70 \%, A=30 \%$; grade of recommendation: $1 \mathrm{C}$

Discussion Both proximally active luminal disease, causing increased bowel frequency, and proctitis are associated with problematic wound healing. ${ }^{86}$ Combined infliximab therapy and surgery has been more successful in the absence of luminal inflammation, especially when localised in the rectum. ${ }^{87}$ Proctitis is also associated with a higher proctectomy rate (29$77.6 \%) .{ }^{26}{ }^{88}$ Therefore, active luminal disease in pCD is an indication for aggressive medical treatment. ${ }^{88}$

\section{Statement 20-Fistulotomy}

Fistulotomy is a treatment option for symptomatic superficial and, occasionally, low intersphincteric fistulas, always with consideration for preservation of continence. Performing fistulotomy in low transsphincteric fistulas, especially if anteriorly located in women, is associated with a high risk of incontinence.

Vote: $A+=60 \%, A=35 \% A-=5 \%$; grade of recommendation: $2 \mathrm{C}$

Discussion In symptomatic superficial, low intersphincteric and selected low transsphincteric fistulas, fistulotomy or lay-open is a safe method, which preserves the continence and offers high healing and low recurrence rates in the absence of proctitis (table 4). In contrast, fistulotomy for high transsphincteric, suprasphincteric and extrasphincteric fistulas is associated with decreased healing and increased incontinence rates. ${ }^{89}$ Furthermore, as the anterior part of the external anal sphincter is shorter in women, fistulotomy for low transsphincteric fistulas carries a higher risk of incontinence.

\section{Statement 21—Definitive surgical repair}

Options for definitive surgical repair of pCD include fistulotomy, mucosal advancement flaps (MAFs), bioprosthetic plugs, and ligation of the intersphincteric fistula tract (LIFT). The use of fibrin glue and stem cell injections is not well established yet. Vote: $A+=20 \%, A=35 \%, a-=40 \%, D=5 \%$; grade of recommendation: $2 \mathrm{C}$

\section{Discussion}

Mucosal advancement flap (MAF) is a surgical treatment option for the closure of internal fistula openings. It entails mobilisation of a rectal mucosal flap to cover the primary fistula opening, thereby closing the high pressure end of the fistula,

Table 4 Fistulotomy in low fistulas

\begin{tabular}{|c|c|c|c|c|}
\hline Study & Patients & $\begin{array}{l}\text { Healing } \\
(\%)\end{array}$ & $\begin{array}{l}\text { Recurrence } \\
(\%)\end{array}$ & $\begin{array}{l}\text { Incontinence } \\
(\%)\end{array}$ \\
\hline $\begin{array}{l}\text { Hobbiss and } \\
\text { Schofield }^{109}\end{array}$ & 32 & 90 & 22 & ns \\
\hline Keighley and Allan ${ }^{110}$ & 12 & 8 & ns & 50 \\
\hline Williams et $\left.a\right|^{89}$ & 41 & 93 & ns & 21 \\
\hline Halme and Sainio ${ }^{111}$ & 10 & 100 & 40 & 50 \\
\hline $\begin{array}{l}\text { Scott and } \\
\text { Northover }^{112}\end{array}$ & 27 & 81 & ns & 19 \\
\hline McKee and Keenan ${ }^{113}$ & 34 & 62 & 18 & ns \\
\hline Michelassi et al ${ }^{114}$ & 33 & 82 & ns & ns \\
\hline Lozynskyy ${ }^{115}$ & 30 & 83 & 17 & 10 \\
\hline van Koperen et al ${ }^{116}$ & 28 & 82 & 18 & 66 \\
\hline
\end{tabular}


Table 5 Fibrin glue

\begin{tabular}{|c|c|c|c|c|}
\hline Study & Type & Patients & FU & Endpoint \\
\hline Grimaud et al ${ }^{117}$ & RCT & 77 & $\begin{array}{l}8 \text { weeks } \\
37 \text { months (median) }\end{array}$ & $\begin{array}{l}\text { Clinical remission: } \\
38 \% \text { vs } 16 \% \text { placebo }(p=0.04) \\
18 \%\end{array}$ \\
\hline Lindsey et $a l^{118}$ & RCT & 42 & 12 weeks & $\begin{array}{l}\text { Cessation of drainage: } \\
\text { Simple: } 50 \% \text { vs } 100 \% \text { fistulotomy }(p=0.06) \\
\text { Complex: } 69 \% \text { vs } 13 \% \text { seton } \pm \text { flap }(p=0.003)\end{array}$ \\
\hline Witte et al ${ }^{119}$ & $\mathrm{OL}$ & 34 & 7 months (median) & Fistula closure: $55 \%$ \\
\hline Vitton et al ${ }^{120}$ & $\mathrm{OL}$ & 14 & $\begin{array}{l}3 \text { months } \\
23 \text { months (median) }\end{array}$ & Fistula closure: $\begin{array}{r}71 \% \\
57 \%\end{array}$ \\
\hline de Parades et $a l^{121}$ & $\mathrm{OL}$ & 30 & $\begin{array}{l}4 \text { weeks } \\
12 \text { months (median) }\end{array}$ & $\begin{aligned} \text { Fistula closure: } & 57 \% \\
& 50 \%\end{aligned}$ \\
\hline Loungnarath et $a l^{122}$ & Retro & 13 (Crohn) & 26 months (median) & Fistula closure: $31 \%$ \\
\hline Zmora et al ${ }^{123}$ & Retro & 24 & 12 months (mean) & Fistulae closure: $33 \%$ \\
\hline Sentovich $^{124}$ & Retro & 20 & 10 months (mean) & Fistula closure: $85 \%$ \\
\hline
\end{tabular}

FU, follow-up; OL, open label; RCT, randomised controlled trial; Retro, retrospective.

whereas the sphincter complex remains untouched. The excluded fistula segment is expected to dry out over time. In a systematic review of 35 studies with an average follow-up of 28.9 months, the success rate of MAF for Crohn's fistulas was $64 \%$ (range 33.3-92.9\%). The incontinence rate was 9.4\% with a wide interstudy variability (range 0-28.6\%). Re-interventions were needed in almost $50 \%$ of patients. ${ }^{90}$

Plugs, made of collagen, or more recently porcine intestinal submucosa, are inserted via the internal fistula opening to fill the fistula tract and leave the sphincter apparatus untouched. Success rates in retrospective cohorts and one open label study with a median follow-up of 6-15 months varied between 24-88\%. ${ }^{91-94}$ One of the studies reported that failure was caused by dislodgement of the plug in $22 \%$ of the cases; however, the closure rate was reported as excellent (87\%) when a suturable bioprosthetic plug was used. ${ }^{95}$ In general, plugs may offer a valid first line option for surgical treatment; measures to prevent dislodgement and perioperative antibiotics may increase success and safety, although costs can be a major concern.

Ligation of the intersphincteric fistula tract (LIFT) is a surgical option in the management of transsphincteric fistulas when the tract has matured into a fibrotic tube with granulation tissue enabling ligation and transection. ${ }^{96}$ The procedure is based on closure of the internal opening and removal of infected tissue via an intersphincteric approach. In the first small case series, a 94\% success rate was reported and these results were confirmed by a pilot study including 40 patients ${ }^{9697} \mathrm{~A}$ recent study showed more moderate success rates $(56 \%$ healing $>1$ year) and all recurrences were within 2 months after the surgery. ${ }^{98}$ Prospective studies with higher numbers of Crohn's patients are further awaited.

Fibrin glue consists of fibrinogen and thrombin. Upon mixing, a fibrin clot is formed, which is thought to stimulate wound healing by inducing angiogenesis and fibroblast growth. Data show varying success rates for fistula closure, which may be due to the heterogeneity of the studies regarding fistula origin (Crohn's vs cryptoglandular) and follow-up (table 5). A meta-analysis found no significant difference between fibrin glue and conventional surgery with regard to recurrence and faecal incontinence rates. $^{99}$

Stem cell based therapy Mesenchymal stem cells have a high degree of plasticity and ability to modulate immune cells. Perior intrafistular injection of autologous expended adipose derived stem cells, as well as bone marrow derived stem cells, were previously proven to be feasible and safe. ${ }^{100-102}$ Initial results show that stem cell \pm fibrin glue treatment induces fistula closure in $56-82 \%$ of patients (vs $16 \%$ in the fibrin glue treated patients, $\mathrm{p}<0.001$ ), and $53 \%$ and $30 \%$ of patients sustained fistula remission at 1 and 3 years, respectively. ${ }^{103-106}$ Although these initial results on stem cell based therapy seem promising, results of further randomised, placebo controlled, ongoing trials on Crohn's fistulas are needed.

Gracilis muscle transposition In a single retrospective study including $18 \mathrm{CD}$ patients, gracilis transposition was successful for complex fistulas in $64 \%$ and for persistent non-healing perineal sinuses in $50 \%$ of the cases with maintained efficacy $(90 \%$ upon 10 months median follow-up). ${ }^{107}$

\section{Statement 22-Diverting stoma}

A diverting temporary stoma is an option for patients with severe, complicated, therapy refractory pCD.

Vote: $A+=80 \%, A=20 \%$; grade of recommendation: $1 \mathrm{C}$

\section{Statement 23-Proctectomy}

Transperineal intersphincteric close rectal proctectomy with permanent stoma is the treatment of last resort in severe, therapy refractory fistulising disease.

Vote: $A+=60 \%, A=35 \%, A-=5 \%$; grade of recommendation: $1 \mathrm{C}$

Table 6 Diverting stoma and proctectomy

\begin{tabular}{llllll}
\hline Study & Patients & FU (months) & Sustained remission (\%) & Proctectomy (\%) & Restored (\%) \\
\hline Yamamoto et al & 31 & $103(13-332)$ & 26 & 68 & 10 \\
Bell et al ${ }^{126}$ & 34 & $\mathrm{~ns}$ & $\mathrm{~ns}$ & 53 & $\mathrm{~ns}$ \\
Guillem et $a l^{126}$ & 28 & $72(24-252)$ & 50 & 51 & $\mathrm{~ns}$ \\
Rehg et $a l^{127}$ & 13 & 60 & 30 & 15 & 30 \\
\hline
\end{tabular}

FU, follow-up; ns, not stated. 


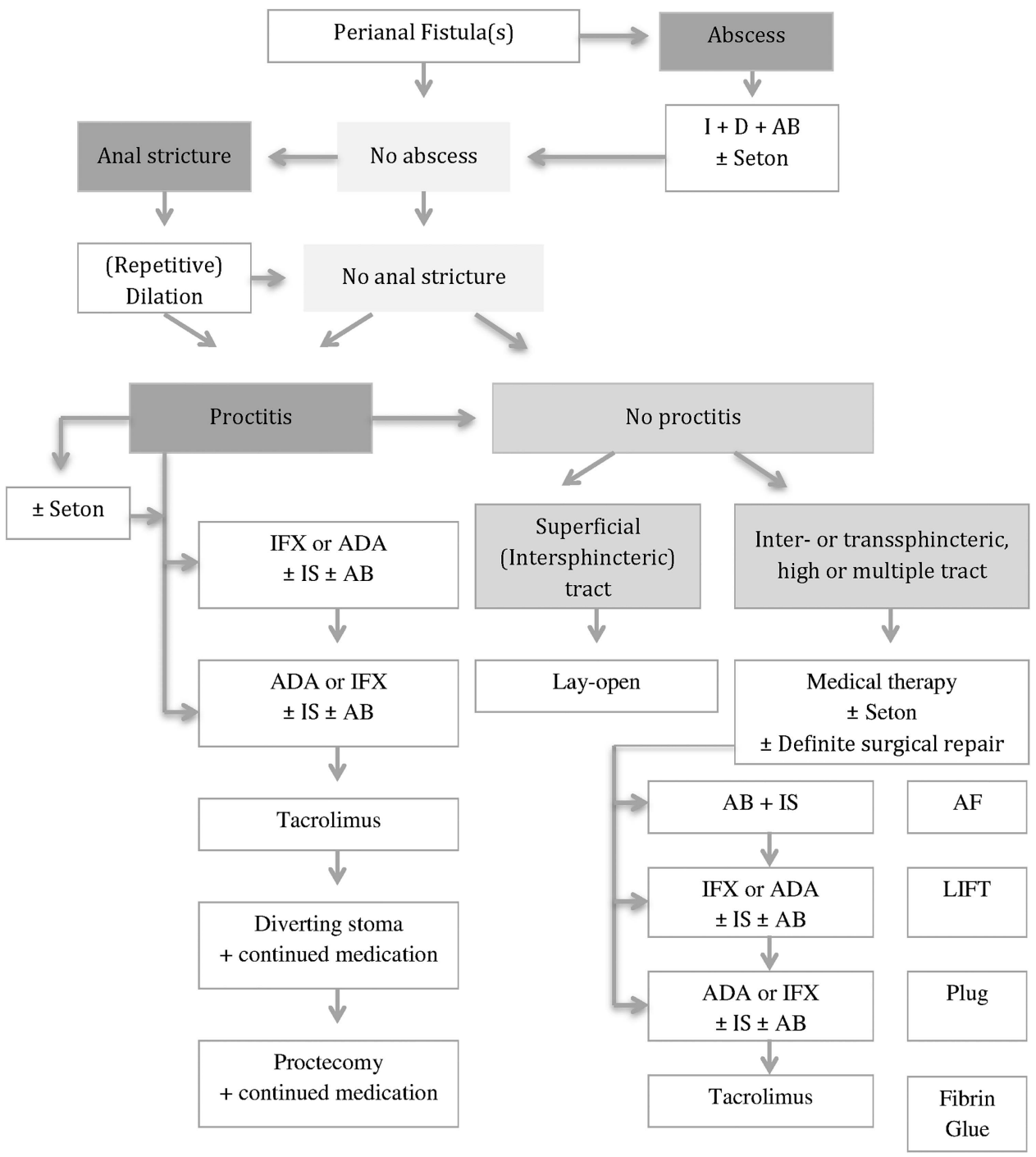

Figure 5 Treatment algorithm for perianal fistulising Crohn's disease. AB, antibiotics; ADA, adalimumab; AF, advancement flap; $D$, drainage; I, incision; IFX, infliximab; IS, immunosuppressants; LIFT, ligation of the intersphincteric fistula tract.

Discussion In complicated, therapy refractory perianal disease a defunctioning stoma should be considered. Based on retrospective data, early remission rates are quite high (up to $81 \%$ ); however, sustained remission can only be achieved in $26-50 \%$ of cases (table 6). Most patients with a stoma ultimately require proctectomy and intestinal continuity can only be restored in a minority of patients. ${ }^{26}$ The only study that was conducted in the era of biologicals showed a reduced need for completion proctectomy and a relatively higher rate of restoration. Main risks of proctectomy include damage to the pelvic nerves, presacral abscesses, and delayed perineal wound healing. Overall, the use of a diverting stoma should be reserved for patients who have uncontrollable sepsis and tissue destruction, or for patients who have failed conservative therapy. Alternatively, in selected patients, permanent faecal diversion can be avoided by coloanal pull-through or Turnbull-Cutait abdominoanal pull-through procedures, provided that the colon and the anus are intact.

\section{CONCLUSIONS}

Optimal management of pCD requires a multidisciplinary approach. Diagnostic accuracy is usually achieved by a combination of modalities. Surgical drainage of sepsis is the first line therapy before initiating immunosuppressive treatment. Antibiotics and thiopurines are recommended as adjunctive treatments in Crohn's fistulas. Of all available anti-TNF agents, the efficacy of infliximab is best documented. Anti-TNF can be used as first line medical treatment, optionally in combination with antibiotics and/or thiopurines. Oral tacrolimus is an option in therapy refractory patients in an attempt to avoid surgical stoma. Definitive surgical repair of fistulas, including fistulotomy, MAF, LIFT, plug and glue, is only of consideration in the absence of luminal inflammation. Proctectomy with permanent stoma is the last resort for severe, therapy refractory disease. A combined medical and surgical treatment algorithm is proposed in figure 5 .

\footnotetext{
Author affiliations

${ }^{1}$ Department of Gastroenterology and Hepatology, Academic Medical Center, University of Amsterdam, Amsterdam, The Netherlands

${ }^{2}$ Robarts Research Institute, Amsterdam, The Netherlands

${ }^{3}$ Department of Surgery, Academic Medical Center, University of Amsterdam, Amsterdam, The Netherlands

${ }^{4}$ St. Vincent's Hospital and University of Melbourne, Melbourne, Australia

${ }^{5}$ Department of Radiology, Academic Medical Center, University of Amsterdam, Amsterdam, The Netherlands

${ }^{6}$ Robarts Research Institute, London, Ontario, Canada
} 
7 University of Western Ontario, London, Ontario, Canada

${ }^{8}$ Department of Medicine and Therapeutics, Institute of Digestive Disease, Prince of Wales Hospital, Chinese University of Hong Kong, Hong Kong, Hong Kong ${ }^{9}$ Department of Gastroenterology, Hospital Clinic Barcelona, IDIBAPS, CIBERehd, Barcelona, Spain

${ }^{10}$ Department of Gastroenterology, University of Leuven, Leuven, Belgium ${ }^{11}$ Department of Gastroenterology, Shanghai Tenth People's Hospital, Tongji University, Shanghai, China

${ }^{12}$ APRG, Imperial College, London, UK

${ }^{13}$ IBD Unit, St. Mark's Hospital, London, UK

${ }^{14}$ Robarts Research Institute, San Diego, CA, USA

${ }^{15}$ Division of Gastroenterology, University of California San Diego, La Jolla, California, USA

Acknowledgements We thank Adam Baker from the University of Western Ontario for his help in conducting the literature search.

Collaborators On behalf of the WCOG Working Party: Guillaume Bouguen: Robarts Research Institute, Amsterdam, The Netherlands, London, Ontario, Canada and San Diego, California, USA, and Service des Maladies de I'Appareil Digestif et INSERM U991, Centre Hospitalier Universitaire Pontchiallou et Université de Rennes 1, Rennes, France; Andreas Sturm: Department of Gastroenterology, Krankenhaus Waldfriede, Charité Universitätsmedizin, Berlin, Germany; Andre D'Hoore Department of Surgery, University of Leuven, Leuven, Belgium; David Laharie: CHU de Bordeaux, Hospital Haut-Lévêque, Bordeaux, France; Brian Feagan: Robarts Research Institute, Amsterdam, The Netherlands, London, Ontario, Canada and San Diego, California, USA and University of Western Ontario, London, Ontario, Canada William Sandborn: Robarts Research Institute, Amsterdam, The Netherlands, London, Ontario, Canada and San Diego, California, USA and Division of Gastroenterology, University of California San Diego, La Jolla, California, USA; Bruce Sands: Mont Sinai Medical Center, New York, New York, USA; Jean-Frederic Colombel: Mont Sinai Medical Center, New York, New York, USA.

Contributors KG performed systematic literature searches, drafted statements and algorithms and drafted the supporting text for the manuscript. WAB contributed with surgical aspects on finalising statements about classification and surgical treatment, revised the algorithm on management and the supporting text on surgical treatment. MAK contributed with practical aspects on improving all statements, revised the algorithms and the supporting text. IS contributed to optimising statements and the algorithm on diagnosis and carefully revised the corresponding supporting text. RK performed systematic literature searches and drafted statements on diagnosis. SCN, JP, GVA, ZL and AH contributed to optimising statements and algorithms during the whole preparation process and carefully revised the supporting text. BGL performed systematic literature searches, drafted statements on medical treatment and drafted the corresponding supporting text. GD'H took the initiative for this Expert Consensus, supervised each step of the process, and made final revisions of the supporting text.

Funding Financial support was provided by a standard grant for Working Party Report from the World Gastroenterology Organization (WGO) and Robarts Research Institute. The proposal was initially developed and supported by the International Organization for the study of Inflammatory Bowel Diseases (IOIBD) and the European Society of Coloproctology (ESCP). The pharmaceutical industry was excluded from all stages of the process.

Competing interests KBG reports having received speakers' honoraria from MSD JS has a consultancy agreement with Robarts Clinical Trials. RK and ZL have no conflicts of interest to declare. JP reports grants and personal fees from Abbvie and MSD, and personal fees from BMS, Boehringer-Ingelheim, BMS, Janssen, RocheGenentech, Novo Nordisk, Nutrition Science Partners, Pfizer, Tygenix, and Topivert. SCN reports having received speakers' honoraria from Janssen and Ferring Pharmaceuticals. She has received research grants from Janssen and Ferring Hong Kong. AH has received consulting fees from Abbott Laboratories/AbbVie, Atlantic Healthcare Limited, Bristol Meyers Squibb, Ferring Pharmaceuticals, Shire Pharmaceuticals, Schering Plough Corporation (acquired by Merck), Warner Chilcott UK Limited and Tillotts Pharma. She has received lecture honoraria from Abbott Laboratories/AbbVie, Ferring Pharmaceuticals, Shire Pharmaceuticals, Schering Plough Corporation (acquired by Merck), Warner Chilcott UK Limited. She has received research funding from Abbott Laboratories/AbbVie, Cook Pharmaceutical, MSD. GB has received lecture fees from Abbvie, Ferring, and MSD Pharma. WS reports having received consulting fees from Abbott Laboratories, ActoGeniX NV, AGl Therapeutics Inc, Alba Therapeutics Corporation, Albireo, Alfa Wasserman, Amgen, AM-Pharma BV, Anaphore, Astellas Pharma, Athersys, Inc., Atlantic Healthcare Limited, Axcan Pharma (now Aptalis), BioBalance Corporation, Boehringer-Ingelheim Inc, Bristol Meyers Squibb, Celegene, Celek Pharmaceuticals, Cellerix SL, Cerimon Pharmaceuticals, ChemoCentryx, CoMentis, Cosmo Technologies, Coronado Biosciences, Cytokine Pharmasciences, Eagle Pharmaceuticals, Eisai Medical Research Inc, Elan Pharmaceuticals, EnGene, Inc, Eli Lilly, Enteromedics, Exagen Diagnostics, Inc, Ferring Pharmaceuticals, Flexion Therapeutics, Inc, Funxional Therapeutics Limited, Genzyme Corporation, Genentech (now Roche), Gilead Sciences, Given Imaging, Glaxo Smith Kline, Human Genome Sciences, Ironwood Pharmaceuticals (previously Microbia Inc), Janssen (previously (entocor), KaloBios Pharmaceuticals, Inc, Lexicon Pharmaceuticals, Lycera Corporation, Meda Pharmaceuticals (previously Alaven Pharmaceuticals), Merck Research Laboratories, MerckSerono, Millennium Pharmaceuticals (subsequently merged with Takeda), Nisshin Kyorin Pharmaceuticals Co, Ltd, Novo Nordisk A/S NPS Pharmaceuticals, Optimer Pharmaceuticals, Orexigen Therapeutics, Inc, PDL Biopharma, Pfizer, Procter and Gamble, Prometheus Laboratories, ProtAb Limited, Purgenesis Technologies, Inc, Receptos, Relypsa, Inc, Salient Pharmaceuticals, Salix Pharmaceuticals, Inc, Santarus, Schering Plough Corporation (acquired by Merck), Shire Pharmaceuticals, Sigmoid Pharma Limited, Sirtris Pharmaceuticals, Inc (a GSK company), S.L.A. Pharma (UK) Limited, Targacept, Teva Pharmaceuticals, Therakos, Tillotts Pharma AG (acquired by Zeria Pharmaceutical Co, Ltd), TxCell SA, UCB Pharma, Viamet Pharmaceuticals, Vascular Biogenics Limited (VBL), Warner Chilcott UK Limited, Wyeth (now Pfizer). He has received lecture fees from Abbott Laboratories, Bristol Meyers Squibb, and Janssen (previously Centocor). He has received research support from Abbott Laboratories, Bristol Meyers Squibb, Genentech, Glaxo Smith Kline, Janssen (previously Centocor), Millennium Pharmaceuticals (now Takeda), Novartis, Pfizer, Procter and Gamble Pharmaceuticals, Shire Pharmaceuticals, and UCB Pharma. BGL reports having received consulting fees from Prometheus Labs, and Santarus Inc, speakers' honoraria from Warner Chilcott, and UCB Pharma. GD'H has received consultancy fees from Abbott Laboratories, Actogenix, Boerhinger Ingelheim, Centocor, Cosmo Technologies, Engene, Ferring Pharmaceuticals, GlaxoSmithKline, Jansen Biologics, Millenium Pharmaceuticals, Mitsubishi Pharma, Merck Research Laboratories, Novo Nordisk, PDL Biopharma, Pfizer, Schering Plough, SetPoint, Shire Pharmaceuticals, Sigmoid Pharma Ltd, Takeda, Teva, Tillotts Pharma, UCB Pharma; research grants from Abbott Laboratories, Jansen Biologics, Given Imaging, MSD, DrFalk Pharma, Photopill; speaking honoraria from Abbott Laboratories, Jansen Biologics, Tillotts, Tramedico, Ferring, MSD, UCB, Norgine and Shire; stock options from Engene Inc.

Provenance and peer review Not commissioned; externally peer reviewed.

\section{REFERENCES}

1 Penner A, Crohn BB. Perianal fistulae as a complication of regional ileitis. Ann Surg 1938;108:867-73.

2 Schwartz DA, Loftus EV Jr, Tremaine WJ, et al. The natural history of fistulizing Crohn's disease in Olmsted County, Minnesota. Gastroenterology 2002;122:875-80

3 Hellers G, Bergstrand O, Ewerth $\mathrm{S}$, et al. Occurrence and outcome after primary treatment of anal fistulae in Crohn's disease. Gut 1980;21:525-7.

4 Bitton A, Buie D, Enns R, et al. Treatment of hospitalized adult patients with severe ulcerative colitis: Toronto consensus statements. Am J Gastroenterol 2012;107:179-94; author reply 95.

5 Guyatt GH, Cook DJ, Jaeschke R, et al. Grades of recommendation for antithrombotic agents: American College of Chest Physicians Evidence-Based Clinical Practice Guidelines (8th edition). Chest 2008;133:123S-31S.

6 Parks AG, Gordon PH, Hardcastle JD. A classification of fistula-in-ano. Br J Surg 1976:63:1-12.

7 Buchmann P, Alexander-Williams J. Classification of perianal Crohn's disease. Clin Gastroenterol 1980;9:323-30.

8 Hughes LE. Clinical classification of perianal Crohn's disease. Dis Colon Rectum 1992;35:928-32.

9 Morris J, Spencer JA, Ambrose NS. MR imaging classification of perianal fistulas and its implications for patient management. Radiographics 2000;20:623-35; discussion 35-7.

10 Sandborn WJ, Fazio WW, Feagan BG, et al. American Gastroenterological Association Clinical Practice C. AGA technical review on perianal Crohn's disease. Gastroenterology 2003;125:1508-30.

11 Present DH, Korelitz BI, Wisch N, et al. Treatment of Crohn's disease with 6-mercaptopurine. A long-term, randomized, double-blind study. N Engl J Med 1980;302:981-7.

12 Allan $\mathrm{A}$, Linares $\mathrm{L}$, Spooner $\mathrm{HA}$, et al. Clinical index to quantitate symptoms of perianal Crohn's disease. Dis Colon Rectum 1992;35:656-61.

13 Irvine EJ. Usual therapy improves perianal Crohn's disease as measured by a new disease activity index. McMaster IBD Study Group. J Clin Gastroenterol 1995:20:27-32.

14 Present $\mathrm{DH}$, Rutgeerts $\mathrm{P}$, Targan $\mathrm{S}$, et al. Infliximab for the treatment of fistulas in patients with Crohn's disease. N Engl J Med 1999;340:1398-405.

15 Pikarsky AJ, Gervaz P, Wexner SD. Perianal Crohn disease: a new scoring system to evaluate and predict outcome of surgical intervention. Arch Surg 2002;137:774-7; discussion 8.

16 Van Assche G, Vanbeckevoort D, Bielen D, et al. Magnetic resonance imaging of the effects of infliximab on perianal fistulizing Crohn's disease. Am J Gastroenterol 2003:98:332-9.

17 Losco A, Vigano C, Conte D, et al. Assessing the activity of perianal Crohn's disease: comparison of clinical indices and computer-assisted anal ultrasound. Inflamm Bowel Dis 2009:15:742-9. 
18 Sandborn WJ, Present DH, Isaacs KL, et al. Tacrolimus for the treatment of fistulas in patients with Crohn's disease: a randomized, placebo-controlled trial. Gastroenterology 2003;125:380-8.

19 Sands BE, Anderson FH, Bernstein CN, et al. Infliximab maintenance therapy for fistulizing Crohn's disease. N Engl J Med 2004;350:876-85.

20 Colombel JF, Sandborn WJ, Rutgeerts $P$, et al. Adalimumab for maintenance of clinical response and remission in patients with Crohn's disease: the CHARM trial. Gastroenterology 2007;132:52-65.

21 Tozer P, Ng SC, Siddiqui MR, et al. Long-term MRI-guided combined anti-TNF-alpha and thiopurine therapy for Crohn's perianal fistulas. Inflamm Bowel Dis 2012;18:1825-34.

22 Horsthuis K, Ziech ML, Bipat S, et al. Evaluation of an MRI-based score of disease activity in perianal fistulizing Crohn's disease. Clin Imaging 2011;35:360-5.

23 Savoye-Collet C, Savoye G, Koning E, et al. Fistulizing perianal Crohn's disease: contrast-enhanced magnetic resonance imaging assessment at 1 year on maintenance anti-TNF-alpha therapy. Inflamm Bowel Dis 2011:17:1751-8.

24 Shenoy-Bhangle A, Nimkin K, Goldner D, et al. MRI predictors of treatment response for perianal fistulizing Crohn disease in children and young adults. Pediatr Radiol 2014;44:23-9.

25 Regueiro M. The role of endoscopy in the evaluation of fistulizing Crohn's disease. Gastrointest Endosc Clin N Am 2002;12:621-33.

26 Bell SJ, Williams AB, Wiesel $P$, et al. The clinical course of fistulating Crohn's disease. Aliment Pharmacol Ther 2003:17:1145-51.

27 Schwartz DA, Wiersema MJ, Dudiak KM, et al. A comparison of endoscopic ultrasound, magnetic resonance imaging, and exam under anesthesia for evaluation of Crohn's perianal fistulas. Gastroenterology 2001;121:1064-72.

28 Regueiro M, Mardini H. Treatment of perianal fistulizing Crohn's disease with infliximab alone or as an adjunct to exam under anesthesia with seton placement. Inflamm Bowel Dis 2003;9:98-103.

29 Halligan S, Stoker J. Imaging of fistula in ano. Radiology 2006;239:18-33.

30 Koelbel G, Schmiedl U, Majer MC, et al. Diagnosis of fistulae and sinus tracts in patients with Crohn disease: value of MR imaging. AJR Am J Roentgenol 1989;152:999-1003.

31 Barker PG, Lunniss PJ, Armstrong P, et al. Magnetic resonance imaging of fistula-in-ano: technique, interpretation and accuracy. Clin Radiol 1994;49:7-13.

32 Haggett PJ, Moore NR, Shearman JD, et al. Pelvic and perineal complications of Crohn's disease: assessment using magnetic resonance imaging. Gut 1995;36:407-10.

33 Bell SJ, Halligan S, Windsor AC, et al. Response of fistulating Crohn's disease to infliximab treatment assessed by magnetic resonance imaging. Aliment Pharmacol Ther 2003;17:387-93.

34 Stoker J, Hussain SM, Van Kempen D, et al. Endoanal coil in MR imaging of anal fistulas. Am J Roentgenol 1996;166:360-2.

35 Law PJ, Bartram Cl. Anal endosonography: technique and normal anatomy. Gastrointest Radiol 1989:14:349-53.

36 Van Outryve MJ, Pelckmans PA, Michielsen PP, et al. Value of transrecta ultrasonography in Crohn's disease. Gastroenterology 1991;101:1171-7.

37 Tio TL, Mulder CJ, Wijers OB, et al. Endosonography of peri-anal and peri-colorectal fistula and/or abscess in Crohn's disease. Gastrointest Endosc 1990;36:331-6

38 Cheong DM, Nogueras JJ, Wexner SD, et al. Anal endosonography for recurrent anal fistulas: image enhancement with hydrogen peroxide. Dis Colon Rectum 1993;36:1158-60.

39 Navarro-Luna A, Garcia-Domingo MI, Rius-Macias J, et al. Ultrasound study of anal fistulas with hydrogen peroxide enhancement. Dis Colon Rectum 2004:47:108-14.

40 Di Nardo R, Drudi FM, Marziale P, et al. [Role of color Doppler echography in the visualization of perianal fistulae with injections of physiologic solutions]. Radiol Med 2000;100:235-9.

41 West RL, Dwarkasing S, Felt-Bersma RJ, et al. Hydrogen peroxide-enhanced three-dimensional endoanal ultrasonography and endoanal magnetic resonance imaging in evaluating perianal fistulas: agreement and patient preference. Eur $\mathrm{J}$ Gastroenterol Hepatol 2004;16:1319-24.

42 Zawadzki A, Starck M, Bohe $M$, et al. A unique 3D endoanal ultrasound feature of perianal Crohn's fistula: the 'Crohn ultrasound fistula sign'. Colorectal Dis 2012;14:e608-11

43 Campari A, Giovanni M, Tonolini M, et al. Accuracy of transperineal ultrasound (TPUS) and magnetic resonance imaging (MRI) in the assessment of perianal Crohn's disease (CD). Dig Liver Dis 2011:43:S134-S5.

44 Sahni VA, Ahmad R, Burling D. Which method is best for imaging of perianal fistula? Abdom Imaging 2008;33:26-30.

45 Orsoni $\mathrm{P}$, Barthet $\mathrm{M}$, Portier $\mathrm{F}$, et al. Prospective comparison of endosonography, magnetic resonance imaging and surgical findings in anorectal fistula and abscess complicating Crohn's disease. Br J Surg 1999;86:360-4.

46 Buchanan GN, Halligan S, Bartram Cl, et al. Clinical examination, endosonography, and MR imaging in preoperative assessment of fistula in ano: comparison with outcome-based reference standard. Radiology 2004:233:674-81.
47 Siddiqui MR, Ashrafian $\mathrm{H}$, Tozer $\mathrm{P}$, et al. A diagnostic accuracy meta-analysis of endoanal ultrasound and MRI for perianal fistula assessment. Dis Colon Rectum 2012;55:576-85.

48 Kuijpers HC, Schulpen T. Fistulography for fistula-in-ano. Is it useful? Dis Colon Rectum 1985:28:103-4.

49 Weisman Rl, Orsay CP, Pearl RK, et al. The role of fistulography in fistula-in-ano. Report of five cases. Dis Colon Rectum 1991:34:181-4

50 Nielsen OH, Munck LK. Drug insight: aminosalicylates for the treatment of IBD. Nat Clin Pract Gastroenterol Hepatol 2007;4:160-70.

51 Jones JH, Lennard-Jones JE. Corticosteroids and corticotrophin in the treatment of Crohn's disease. Gut 1966;7:181-7.

52 Bernstein LH, Frank MS, Brandt LJ, et al. Healing of perineal Crohn's disease with metronidazole. Gastroenterology 1980;79:599.

53 Brandt LJ, Bernstein LH, Boley SJ, et al. Metronidazole therapy for perineal Crohn's disease: a follow-up study. Gastroenterology 1982;83:383-7.

54 Jakobovits J, Schuster MM. Metronidazole therapy for Crohn's disease and associated fistulae. Am J Gastroenterol 1984;79:533-40.

55 Thia KT, Mahadevan U, Feagan BG, et al. Ciprofloxacin or metronidazole for the treatment of perianal fistulas in patients with Crohn's disease: a randomized, double-blind, placebo-controlled pilot study. Inflamm Bowel Dis 2009;15:17-24

56 Maeda $Y, \mathrm{Ng} \mathrm{SC}$, Durdey $\mathrm{P}$, et al. Randomized clinical trial of metronidazole ointment versus placebo in perianal Crohn's disease. Br J Surg 2010;97:1340-7.

57 Stringer EE, Nicholson TJ, Armstrong D. Efficacy of topical metronidazole (10 percent) in the treatment of anorectal Crohn's disease. Dis Colon Rectum 2005:48:970-4.

58 West RL, Woude CJ, Hansen BE, et al. Clinical and endosonographic effect of ciprofloxacin on the treatment of perianal fistulae in Crohn's disease with infliximab: a double-blind placebo-controlled study. Aliment Pharmacol Ther 2004:1329-36.

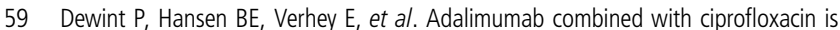
superior to adalimumab monotherapy in perianal fistula closure in Crohn's disease: a randomised, double-blind, placebo controlled trial (ADAFI). Gut 2014;63:292-9.

60 Prefontaine E, Macdonald JK, Sutherland LR. Azathioprine or 6-mercaptopurine for induction of remission in Crohn's disease. Cochrane Database Syst Rev 2010: CD000545.

61 Pearson DC, May GR, Fick GH, et al. Azathioprine and 6-mercaptopurine in Crohn disease. A meta-analysis. Ann Intern Med 1995;123:132-42.

62 Dejaco C, Harrer M, Waldhoer T, et al. Antibiotics and azathioprine for the treatment of perianal fistulas in Crohn's disease. Aliment Pharmacol Ther 2003;18:1113-20.

63 Hart AL, Plamondon S, Kamm MA. Topical tacrolimus in the treatment of perianal Crohn's disease: exploratory randomized controlled trial. Inflamm Bowel Dis 2007;13:245-53.

64 Egan LJ, Sandborn WJ, Tremaine WJ. Clinical outcome following treatment of refractory inflammatory and fistulizing Crohn's disease with intravenous cyclosporine. Am J Gastroenterol 1998;93:442-8.

65 Hanauer SB, Smith MB. Rapid closure of Crohn's disease fistulas with continuous intravenous cyclosporin A. Am J Gastroenterol 1993;88:646-9.

66 Present DH, Lichtiger S. Efficacy of cyclosporine in treatment of fistula of Crohn's disease. Dig Dis Sci 1994;39:374-80.

67 Present $\mathrm{DH}$, Rutgeerts $\mathrm{P}$, Targan $\mathrm{S}$, et al. Infliximab for the treatment of fistulas in patients with Crohn's disease. N Engl J Med 1999;340:1398-405.

68 Sands BE, Anderson FH, Bernstein CN, et al. Infliximab maintenance therapy for fistulizing Crohn's disease. N Engl J Med 2004;350:876-85.

69 Hanauer SB, Sandborn WJ, Rutgeerts $P$, et al. Human anti-tumor necrosis factor monoclonal antibody (adalimumab) in Crohn's disease: the CLASSIC-I trial. Gastroenterology 2006;130:323-32.

70 Sandborn WJ, Rutgeerts P, Enns R, et al. Adalimumab induction therapy for Crohn disease previously treated with infliximab: a randomized trial. Ann Intern Med 2007:146:829-38.

71 Colombel JF, Schwartz DA, Sandborn WJ, et al. Adalimumab for the treatment of fistulas in patients with Crohn's disease. Gut 2009;58:940-8.

72 Echarri A, Castro J, Barreiro $\mathrm{M}$, et al. Evaluation of adalimumab therapy in multidisciplinary strategy for perianal Crohn's disease patients with infliximab failure. J Crohn's Colitis 2010;4:654-60.

73 Lichtiger S, Binion DG, Wolf DC, et al. The CHOICE trial: adalimumab demonstrates safety, fistula healing, improved quality of life and increased work productivity in patients with Crohn's disease who failed prior infliximab therapy. Aliment Pharmacol Ther 2010;32:1228-39.

74 Tozer P, Ng SC, Siddiqui MR, et al. Long-term MRI-guided combined anti-TNFand thiopurine therapy for Crohn's perianal fistulas. Inflamm Bowel Dis 2012:18:1825-34

75 Schreiber S, Lawrance IC, Thomsen 00, et al. Randomised clinical trial: certolizumab pegol for fistulas in Crohn's disease-subgroup results from a placebo-controlled study. Aliment Pharmacol Ther 2011;33:185-93.

76 Ford AC, Sandborn WJ, Khan KJ, et al. Efficacy of biological therapies in inflammatory bowel disease: systematic review and meta-analysis. Am J Gastroenterol 2011:106:644-59, quiz 60. 
77 Colombel JF, Sandborn WJ, Reinisch W, et al. Infliximab, azathioprine, or combination therapy for Crohn's disease. N Engl J Med 2010;362:1383-95.

78 Bouguen $\mathrm{G}$, Siproudhis L, Gizard $\mathrm{E}$, et al. Long-term outcome of perianal fistulizing Crohn's disease treated with infliximab. Clin Gastroenterol Hepatol 2013:8:975-81.

79 El-Gazzaz G, Hull T, Church JM. Biological immunomodulators improve the healing rate in surgically treated perianal Crohn's fistulas. Colorectal Dis 2012;14:1217-23.

80 Solomon MJ. Fistulae and abscesses in symptomatic perianal Crohn's disease. Int J Colorectal Dis 1996;11:222-6.

81 Hyder SA, Travis SP, Jewell DP, et al. Fistulating anal Crohn's disease: results of combined surgical and infliximab treatment. Dis Colon Rectum 2006;49:1837-41.

82 Buchanan GN, Owen HA, Torkington J, et al. Long-term outcome following loose-seton technique for external sphincter preservation in complex anal fistula. Br J Surg 2004:91:476-80.

83 Parks AG, Stitz RW. The treatment of high fistula-in-ano. Dis Colon Rectum 1976;19:487-99.

84 Hamalainen KP, Sainio AP. Cutting seton for anal fistulas: high risk of minor control defects. Dis Colon Rectum 1997;40:1443-6; discussion 7.

85 Tanaka S, Matsuo K, Sasaki T, et al. Clinical advantages of combined seton placement and infliximab maintenance therapy for perianal fistulizing Crohn's disease: when and how were the seton drains removed? Hepatogastroenterology 2010;57:3-7.

86 Nordgren S, Fasth S, Hulten L. Anal fistulas in Crohn's disease: incidence and outcome of surgical treatment. Int J Colorectal Dis 1992;7:214-18.

87 Tougeron D, Savoye G, Savoye-Collet C, et al. Predicting factors of fistula healing and clinical remission after infliximab-based combined therapy for perianal fistulizing Crohn's disease. Dig Dis Sci 2009;54:1746-52.

88 Kamm MA, Ng SC. Perianal fistulizing Crohn's disease: a call to action. Clin Gastroenterol Hepatol 2008;6:7-10.

89 Williams JG, Rothenberger DA, Nemer FD, et al. Fistula-in-ano in Crohn's disease Results of aggressive surgical treatment. Dis Colon Rectum 1991;34:378-84.

90 Soltani A, Kaiser AM. Endorectal advancement flap for cryptoglandular or Crohn's fistula-in-ano. Dis Colon Rectum 2010;53:486-95.

91 O'Connor L, Champagne BJ, Ferguson MA, et al. Efficacy of anal fistula plug in closure of Crohn's anorectal fistulas. Dis Colon Rectum 2006;49:1569-73.

92 Ellis CN, Rostas JW, Greiner FG. Long-term outcomes with the use of bioprosthetic plugs for the management of complex anal fistulas. Dis Colon Rectum 2010;53:798-802

93 Owen G, Keshava A, Stewart $P$, et al. Plugs unplugged. Anal fistula plug: the Concord experience. ANZ J Surg 2010;80:341-3.

94 Lawes DA, Efron JE, Abbas $M$, et al. Early experience with the bioabsorbable anal fistula plug. World J Surg 2008;32:1157-9.

95 Thekkinkattil DK, Botterill I, Ambrose NS, et al. Efficacy of the anal fistula plug in complex anorectal fistulae. Colorectal Dis 2009;11:584-7.

96 Rojanasakul A, Pattanaarun J, Sahakitrungruang C, et al. Total anal sphincter saving technique for fistula-in-ano; the ligation of intersphincteric fistula tract. J Med Assoc Thai 2007;90:581-6.

97 Abcarian AM, Estrada JJ, Park J, et al. Ligation of intersphincteric fistula tract: early results of a pilot study. Dis Colon Rectum 2012;55:778-82.

98 Realis Luc A, Clerico G, Ganio E, et al. Lift for complex anal fistulae: the Colorectal Eporediensis Centre's experience. Tech Coloproctol 2012;16:82-3.

99 Cirocchi R, Santoro A, Trastulli S, et al. Meta-analysis of fibrin glue versus surgery for treatment of fistula-in-ano. Ann Ital Chir 2010:81:349-56.

100 Garcia-Olmo D, Garcia-Arranz M, Herreros D, et al. A phase I clinical trial of the treatment of Crohn's fistula by adipose mesenchymal stem cell transplantation. Dis Colon Rectum 2005:48:1416-23.

101 Ciccocioppo R, Bernardo ME, Sgarella A, et al. Autologous bone marrow-derived mesenchymal stromal cells in the treatment of fistulising Crohn's disease. Gut 2011;60:788-98.
102 Cho YB, Lee WY, Park KJ, et al. Autologous adipose tissue-derived stem cells for the treatment of Crohn's fistula: a phase I clinical study. Cell Transplant 2013:22:279-85.

103 Garcia-Olmo D, Herreros D, Pascual I, et al. Expanded adipose-derived stem cells for the treatment of complex perianal fistula: a phase II clinical trial. Dis Colon Rectum 2009;52:79-86.

104 Guadalajara H, Herreros D, De-La-Quintana P, et al. Long-term follow-up of patients undergoing adipose-derived adult stem cell administration to treat complex perianal fistulas. Int J Colorectal Dis 2012;27:595-600.

105 Lee WY, Park KJ, Cho YB, et al. Autologous adipose tissue-derived stem cells treatment demonstrated favorable and sustainable therapeutic effect for Crohn's fistula. Stem Cells 2013;31:2575-81.

106 de la Portilla F, Alba F, Garcia-Olmo D, et al. Expanded allogeneic adipose-derived stem cells (eASCs) for the treatment of complex perianal fistula in Crohn's disease: results from a multicenter phase I/lla clinical trial. Int J Colorectal Dis 2013;28: 313-23.

107 Maeda Y, Heyckendorff-Diebold T, Tei TM, et al. Gracilis muscle transposition for complex fistula and persistent nonhealing sinus in perianal Crohn's disease. Inflamm Bowel Dis 2011:17:583-9.

108 Gecse K, Khanna R, Stoker J, et al. Fistulizing Crohn's disease: diagnosis and management. United European Gastroenterol J 2013:1:206-13.

109 Hobbiss JH, Schofield PF. Management of perianal Crohn's disease. J R Soc Med 1982;75:414-17.

110 Keighley MR, Allan RN. Current status and influence of operation on perianal Crohn's disease. Int J Colorectal Dis 1986:1:104-7.

111 Halme L, Sainio AP. Factors related to frequency, type, and outcome of anal fistulas in Crohn's disease. Dis Colon Rectum 1995:38:55-9.

112 Scott HJ, Northover JM. Evaluation of surgery for perianal Crohn's fistulas. Dis Colon Rectum 1996;39:1039-43.

113 McKee RF, Keenan RA. Perianal Crohn's disease - is it all bad news? Dis Colon Rectum 1996;39:136-42.

114 Michelassi F, Melis M, Rubin M, et al. Surgical treatment of anorectal complications in Crohn's disease. Surgery 2000;128:597-603.

115 Lozynskyy YS. Treatment algorithms in the case of perianal complications of Crohn's disease. Dig Dis 2009;27:565-70.

116 van Koperen PJ, Safiruddin F, Bemelman WA, et al. Outcome of surgical treatment for fistula in ano in Crohn's disease. Br J Surg 2009;96:675-9.

117 Grimaud JC, Munoz-Bongrand N, Siproudhis L, et al. Fibrin glue is effective in healing perianal fistulas in patients with Crohn's disease. Gastroenterology 2010;138:2275-81, 81 e1.

118 Lindsey I, Smilgin-Humphreys MM, Cunningham C, et al. A randomized, controlled trial of fibrin glue vs. conventional treatment for anal fistula. Dis Colon Rectum 2002:45:1608-15.

119 Witte ME, Klaase JM, Gerritsen JJ, et al. Fibrin glue treatment for simple and complex anal fistulas. Hepatogastroenterology 2007:54:1071-3.

120 Vitton V, Gasmi M, Barthet M, et al. Long-term healing of Crohn's anal fistulas with fibrin glue injection. Aliment Pharmacol Ther 2005;21:1453-7.

121 de Parades V, Far HS, Etienney I, et al. Seton drainage and fibrin glue injection for complex anal fistulas. Colorectal Dis 2010;12:459-63.

122 Loungnarath R, Dietz DW, Mutch MG, et al. Fibrin glue treatment of complex anal fistulas has low success rate. Dis Colon Rectum 2004;47:432-6.

123 Zmora 0, Mizrahi N, Rotholtz N, et al. Fibrin glue sealing in the treatment of perineal fistulas. Dis Colon Rectum 2003;46:584-9.

124 Sentovich SM. Fibrin glue for all anal fistulas. J Gastrointest Surg 2001:5:158-61.

125 Yamamoto T, Allan RN, Keighley MR. Effect of fecal diversion alone on perianal Crohn's disease. World J Surg 2000:24:1258-62; discussion 62-3.

126 Guillem JG, Roberts PL, Murray JJ, et al. Factors predictive of persistent or recurrent Crohn's disease in excluded rectal segments. Dis Colon Rectum 1992:35:768-72.

127 Rehg KL, Sanchez JE, Krieger BR, et al. Fecal diversion in perirectal fistulizing Crohn's disease is an underutilized and potentially temporary means of successful treatment. Am Surg 2009;75:715-18. 